\title{
Writing Tips on Prime and Social Media and Their Needs in The Development of The Knowledge-Savvy Generation
}

Irwan bin Mohd Subri, Nur Sarah binti Tajul Urus

To Link this Article: http://dx.doi.org/10.6007/IJARBSS/v11-i12/11910

DOI:10.6007/IJARBSS/v11-i12/11910

Received: 22 October 2021, Revised: 24 November 2021, Accepted: 04 December 2021

Published Online: 19 December 2021

In-Text Citation: (Subri \& Urus, 2021)

To Cite this Article: Subri, I. bin M., \& Urus, N. S. binti T. (2021). Writing Tips on Prime and Social Media and Their Needs in The Development of The Knowledge-Savvy Generation. International Journal of Academic Research in Business and Social Sciences, 11(12), 1927-1933.

\section{Copyright: (c) 2021 The Author(s)}

Published by Human Resource Management Academic Research Society (www.hrmars.com)

This article is published under the Creative Commons Attribution (CC BY 4.0) license. Anyone may reproduce, distribute, translate and create derivative works of this article (for both commercial and non0-commercial purposes), subject to full attribution to the original publication and authors. The full terms of this license may be seen at: http://creativecommons.org/licences/by/4.0/legalcode

Vol. 11, No. 12, 2021, Pg. $1927-1933$

Full Terms \& Conditions of access and use can be found at http://hrmars.com/index.php/pages/detail/publication-ethics 


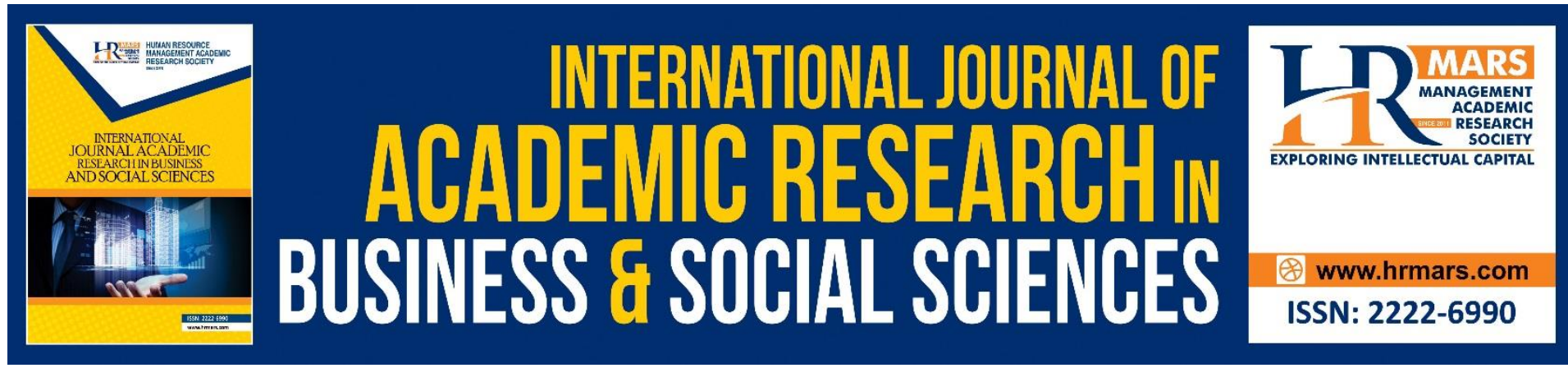

\title{
Writing Tips on Prime and Social Media and Their Needs in The Development of The Knowledge- Savvy Generation
}

\author{
Irwan bin Mohd Subri ${ }^{1}$, Nur Sarah binti Tajul Urus ${ }^{2}$ \\ ${ }^{1}$ Director, Institute of Fatwa and Halal (IFFAH), Professor, Faculty of Syariah and Law, \\ Universiti Sains Islam Malaysia; Secretary, Academy of Figh Islami Malaysia (AFHAM), \\ ${ }^{2}$ Lecturer, Kulliyyah of Shariah and Laws, UniSHAMS. \\ Email: irwan@usim.edu.my, nursarah@unishams.edu.my
}

\begin{abstract}
Academic writing is a type of scientific writing that is done on a regular basis and is methodical and complete in response to a certain subject or issue that arises. One of the constraints of academic writing is how it is conveyed in comprehending society, especially to the younger generation with varying degrees of comprehension. As a result, the purpose of this essay is to provide writing advice in mainstream media as well as social media in order to form the knowledge-savvy generation. This article employs the qualitative approach of content analysis by referring to relevant texts from books, journal articles, and other sources. According to the study's findings, efficient writing techniques may assist authors, particularly academics, in communicating their ideas to society and ensuring that they are understood.
\end{abstract}

Keywords: Writing, Academic, Media, Literacy, Science.

\section{Introduction}

Writing is a mechanism to present thoughts, ideas, or meanings in a simple language by constructing words in the form of sentences so that others may comprehend them (readers).

Abu Bakar (2013) stated, "To be a writer, the fundamental requirement is science, as it is possible to write without a broad and varied knowledge, and for creative writing, as it is claimed to have a skill and creative spirit. Being a writer in a worldwide world with no borders, where the average society is expanding in terms of science and has the ability to obtain information, necessitates a high level of knowledge and creativity."

Writers must like reading, according to (Shaharom, 2019). A bookworm's reading material might inspire a wide range of thoughts. When fresh ideas are developed and critiqued, he has

${ }^{1}$ Director, Institute of Fatwa and Halal (IFFAH), Professor, Faculty of Syariah and Law, Universiti Sains Islam Malaysia; Secretary, Academy of Fiqh Islami Malaysia (AFHAM). irwan@usim.edu.my

${ }^{2}$ Lecturer, Kulliyyah of Shariah and Laws, UniSHAMS. nursarah@unishams.edu.my 
the potential to be an excellent writer. A good reader is not always a good writer. However, a strong writer must be able to read with their feet. Only with 10 ringgit may a person donate a gift or donation of five or ten ringgit. Writers provide presents or charities to their readers.

This is consistent with Allah TAALA's declaration, which connects recitation with the pen:

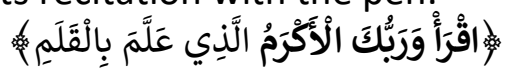

That is to say "Read it, and your Lord is kind. Who instructs man using qalam (pen and paper)?" (Quran). Al-'Alaq: 3-4. Imam al-Qurtubiyy (2006) emphasized in his commentary that the objective of "teaching man through qalam" is to teach man to write with qalam (pen).

In general, the public nowadays receives information from two sources: mainstream media and social media. People need information and knowledge about the economy, health, education, national security, and other topics that affect them directly or indirectly. Governments, corporations, and people may communicate information through media, whether it be mainstream or social media.

The growth of society and the production of the country's cladding is dependent on the type of presentation of information and information from the author's writing. Good writing is necessary for society to receive knowledge. Good and helpful writing will result in a civilized culture and generation. On the other hand, if the content of the writing is poor, it is incapable of developing an informed society and generation.

As a result, this article proposes numerous efficient writing strategies that can assist authors, particularly academics, in presenting their thoughts to the community in a way that they can grasp. Its goal is to create a civilization and a knowledge-savvy generation based on real and truthful facts.

\section{Writing, Prime Media, and Social Media}

Kamus Dewan Dictionary defines writing as "description or action in writing (authoring, etc.)." (Kamus Dewan. Writing) According to Za'ba (1965), writing is "a work of composing words in a nice order since it is a heart or a tale so that others may understand when they are heard or read the arrangement." Writing, according to Sariyan (1991), refers to the processing of ideas or thoughts, as well as the mechanical processes that entail the mastery of tools and techniques to communicate ideas or thoughts.

It is possible to infer that writing is a concept that is transmitted through words constructed in entire sentences. It used to take the shape of notes on stones, tree fronds, stones, animal bark, and other materials. Then the paper took over as a medium for idea posting, and now the digital platform is also one of the media for idea posting. Among the goals of writing are to:

i. convey ideas and information.

ii. clarify a situation.

iii. clearing up ambiguity in a situation.

Media, on the other hand, are communication instruments or intermediates (communications), such as radio, television, and newspapers. The mass media is a broad range of communication instruments (such as television, radio, newspapers, magazines, and 
so on) that may swiftly (in a short period of time) communicate information (news and so on) to the general population (Kamus Dewan. Media).

The term premier implies "the major one" (Kamus Dewan. Perdana). The term "social" refers to "anything relating to society, community, community" (Kamus Dewan. Sosial). Social media is a sort of online communication channel that allows users to freely engage, share, and debate content using a multimedia combination of text, photographs, video, and voice (MAMPU, 2015).

In the context of this article, the term "mainstream media" refers to the daily newspaper. It is available in two forms: printed and online. Meanwhile, social media is intended to be an online social communication platform.

According to Jasin (2019), when compared to social media, the mainstream media is still the most reliable source of information. He stated that persons working in the mainstream media sector are professionals who are trained, accredited, and licensed, but are subject to the law and must always follow ethics when gathering material. The mainstream media consists not only of journalists, but also of authors and news editors who assure the veracity and authenticity of confirmed sources of information.

He also stated that "It is not a news source, unlike social media. It is just social media that anyone may use to say whatever they want, just like in a coffee shop. As a result, we should avoid sources on social media since true information can only be gained through newspapers, radio, internet, and television ".

According to Dr. Noor Nirwandy Mat Noordin, Senior Lecturer at the School of Media and Information Warfare, Universiti Teknologi Mara (UiTM), the importance of the media sector, particularly mainstream media, should be recognized since it represents the identity of society and the country. The mainstream media is desperately needed to counter the spread of fake news, which has a negative impact on society (Harian, 2020).

Today, social media is a vast communication network for people from all walks of life, regardless of whether they are teens, adults, or leaders (MAMPU, 2015).

Social networking offers an easy way to organize material. Social network administrators can post material in a variety of formats, including videos, music, photographs, and documents. Through this medium, the agency may give clarity and a more accurate image of the topics being discussed among social media users. As a result, it has the potential to improve integrity in the government's decision-making and policy-making processes.

However, for the objective of community development and knowledge-savvy generation, writing by a writer, particularly academicians, whether in prime media or social media, should contain material that improves the reader's mind. Otherwise, that goal will not be met.

\section{Tips For The Development of The Knowledge-Literate Generation}

Here are some writing recommendations for a rising culture and literate generation:

\section{Guide Readers in the Direction of Allah SWT}

The author's obligation extends beyond just conveying any notion or concept. The most significant aspect is that in each of his publications, he strives to urge the reader to follow the 
teachings of Islam. Writing is also a sort of da'wah in which goodwill is conveyed to the reader in order for them to obey Allah SWT and His Messenger.

According to Allah SWT:

$$
\text { 罗弯 }
$$

The verse states, "Call upon the way of your Lord with knowledge and excellent teaching advice." (al-Quran. Al-Nahlu: 125).

\section{Writing in Areas of Expertise}

It is preferable for an academician to expand his writing in his field of competence. This is due to the fact that he is an expert in the subject, and his writing on that topic will have a high and dependable authority value. When numerous professionals in their area write in their field, it can balance the writing of individuals who are not members of their field who are distant from principles and disciplined in a particular field of study.

According to Allah SWT:

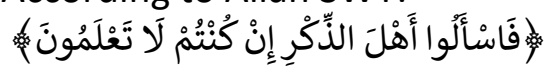

The verse states, "Ask ahlu al-dhikri (field expert) if you do not know." (al-Quran. Al-Anbiya': 7).

\section{Writing Style That is not Too Bombastic}

The bulk of readers in mainstream media and social media are public or students. It is vital to utilize straightforward and non-bombastic language to guarantee that the author's thoughts are understood and relevant to the intended audience. It is thought that if a high language barrel is used, which is overly lyrical and scholarly, the average audience may find it difficult to grasp. It is like a self-conscious writer who only understands himself.

According to Saidina 'Aliyy RA,

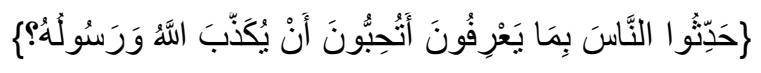

Hadith Interpretation, "Speak to the people in their language; do you want God and His Messenger to lie?" (Al-Bukhari, Hadith). When interpreting this hadith, Ibnu Hajar al'Asqalaniyy (t.th) stated, "this shows that deceptive matters (al-mutashabih) should not be addressed in public."

\section{There are Facts and References in This Document}

An excellent piece of writing should be led by clear facts rather than merely careless writing. Its purpose is to increase the reader's faith in the material given while removing any prejudice or suspicion.

In a hadith recounted by Abu Hurayrah RA, the Prophet PBUH said:

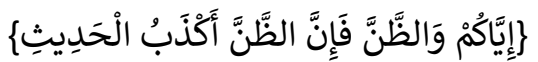

That is, "avoid harmful preconceptions, for ill prejudice is the most misleading discourse" (Hadith. al-Bukhari).

Scholarly writing, by definition, necessitates citation. While references are not required for semi-scientific or unscientific writing, they are recommended. This implies that the author has credibility and is accountable for his writing. It will also boost the reader's trust in the author. 


\section{Not Intimidating or Sarcastic}

A good writer will make friends and admirers via his work. As a result, if the author desires to chastise any party, whether individual or organizational, offensive and caustic language should be avoided. This is because the rebuke to be delivered in writing includes an element of explanation and factual correction, among other things. The side that desires to be scolded is more acceptable if it is done correctly.

Allah SWT states that insults and insinuation are prohibited:

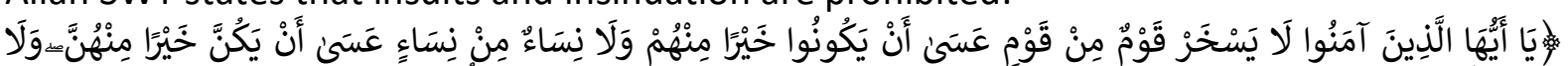

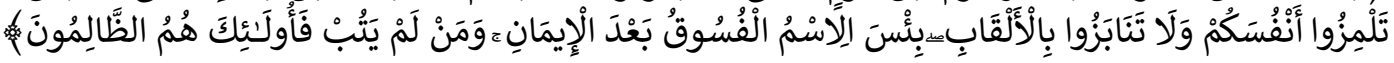
"O ye who have believed! Let no group make fun of another side, even if it is superior to them. And let no one group of women make fun of another faction of women, for the others could be better than them. And none of you should declare the other's lie. And do not give each other a poor title. These restrictions force the wicked to be rebellious, hence evil is the pronunciation of a person who is defiant after believing. And those who do not repent are the wrongdoers." Al-Hujurat: 11).

Similarly, the Prophet PBUH described it in a hadith given by Abu Hurayrah RA:

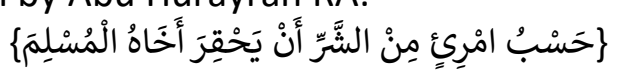

"It is enough for a guy to be deemed to have done evil if he demeans his Muslim brother." (Hadis. Ibnu Majah).

\section{Conclusion}

Writing requires a great deal of trust and responsibility. The significance of writing was recorded in the first revelation of surah al-'Alaq. A writer should not be reckless in presenting his views through writing. Many academics are encouraged to write in order to share useful ideas and information. This is to realize the objective to build and grow a knowledge-savvy generation.

When there is a lot of writing that develops the intellect, it can minimize the bad effects on society. The writing tips offered in this brief post are not confined to that. It is simply basic guidance for all authors who desire to write in both mainstream media and social media. Effective writing may assist authors, particularly academics, in communicating their views to society, and it is widely understood by them.

\section{Acknowledgment}

This research received specific funding for ERA publication from UniSHAMS Research Cluster Serial Webinar 2021: 1 st and 2nd Series, on 22nd September and 13th October 2021 at UniSHAMS, Kuala Ketil, Baling, Kedah, Darul Aman, Malaysia.

\section{Corresponding Author}

Irwan bin Mohd Subri

Director, Institute of Fatwa and Halal (IFFAH), Professor, Faculty of Syariah and Law, Universiti Sains Islam Malaysia; Secretary, Academy of Fiqh Islami Malaysia (AFHAM).

Email: irwan@usim.edu.my 


\section{References}

Sariyan, A. (1991). Kemahiran Penulisan Dalam Konteks Pembinaan Wacana Yang Utuh. Jurnal Dewan Bahasa, 8, 715-717.

Al-Qurtubiyy, M. bin A. (2006). Tafsir al-Qurtubiyy (al-Jami' Li Ahkam al-Qur'an). T.tp: Mu'assasat al-Risalah.

Unit Pemodenan Tadbiran dan Perancangan Pengurusan Malaysia (MAMPU). 2015. Penerapan Etika Penggunaan Media Sosial Dalam Sektor Awam. Putrajaya.

Za'ba. (1965). Ilmu Mengarang Melayu. Kuala Lumpur: Dewan Bahasa dan Pustaka.

\section{Internet Sources}

Jasin, K. (2019). Berita Harian Online. Media Arus Perdana Masih Sumber Berita Utama, Benar Dan Perlu Diyakini - Kadir Jasin.

https://www.bharian.com.my/berita/nasional/2019/09/610112/media-arus-perdanamasih-sumber-berita-utama-benar-dan-perlu-diyakini

Kamus Dewan. Dewan Bahasa dan Pustaka. Edisi Keempat. Media.

https://prpm.dbp.gov.my/Cari1?keyword=media\&d=175768\&

Kamus Dewan. Dewan Bahasa dan Pustaka. Edisi Keempat. Penulisan. https://prpm.dbp.gov.my/cari1?keyword=penulisan

Kamus Dewan. Dewan Bahasa dan Pustaka. Edisi Keempat. Perdana. https://prpm.dbp.gov.my/Cari1?keyword=perdana

Kamus Dewan. Dewan Bahasa dan Pustaka. Edisi Keempat. Sosial. https://prpm.dbp.gov.my/Cari1?keyword=sosial

Abu Bakar, S. (2013). Minat Menulis? Tuntutan Keperluan. http://drshafie.blogspot.com/2013/06/minat-menulis-tuntutan-keperluan.html

Harian, S. (2020). Media Arus Perdana Cerminan Negara. https://www.sinarharian.com.my/article/82953/BERITA/Nasional/Media-arusperdana-cerminan-negara

Harian, S. (2019). Penulis Dan Penulisan.

https://www.sinarharian.com.my/article/59419/KOLUMNIS/Penulis-dan-penulisan 